\title{
The Federal Election Commission, The
}

\section{First Amendment, and Due Process*}

The Federal Election Commission (FEC), established in 1974, is responsible for civil enforcement of the federal campaign finance laws. After the Supreme Court declared much of the 1974 legislation unconstitutional in $1976,{ }^{1}$ Congress passed new legislation reestablishing the FEC, although altering its method of appointment and its enforcement procedures. ${ }^{2}$ Further statutory changes, both substantive and procedural, were adopted in $1979 .^{3}$

From its inception, the FEC received severe criticism for its enforcement procedures. ${ }^{4}$ The 1976 campaign finance legislation failed to provide sufficient procedural safeguards for respondents. Thus, in cases with complex and disputed issues of fact or law, the procedures operated arbitrarily and unfairly, burdening political activity protected by the First Amendment.

This Note argues that, despite the recent statutory changes, the FEC's enforcement procedures still threaten serious unfairness and excessive expense to respondents. ${ }^{5}$ Thus, the Note contends, these procedures

- This Note relies heavily on the author's interviews with present and former FEC commissioners, attorneys, and staff, counsel to respondents in enforcement cases, spokesmen for political and party committees, and congressional committee personnel. Some of these sources requested confidentiality because of their current positions or continued dealings with the FEC. The Note also relies on 35 responses to questionnaires sent by the author to signers of conciliation agreements and their counsel and on the author's review of enforcement files in closed FEC cases, available in the Public Records Office of the FEC in Washington, D.C. Cited materials are on file with the Yale Law Journal.

1. Buckley $v$. Valeo, 424 U.S. 1 (1976). The Court found that congressional selection of four of the six voting FEC members violated art. 2, $\$ 2$ of the Constitution. Id. at 120-41. It also struck down statutory limits on campaign expenditures by candidates and independent expenditures by individuals on behalf of candidates. $I d$. at 39-59.

2. 2 U.S.C. $\$ \$ 431-455 ; 26$ U.S.C. $\$ \$ 9001-9012,9031-9042$ (1976).

3. Federal Election Campaign Act Amendments of 1979, Pub. L. No. 96-187, 93 Stat. 1339 (1980) (codified at 2 U.S.C.A. $\$ \$ 431-441$ (West Supp. 1980)).

4. See 125 Cong. Rec. S11,212-15 (daily ed. Aug. 1, 1979) (remarks of Sen. Humphrey); Bolton, Government Astride the Political Process, Reguldtion, July/August 1978, at 46, 50.51; Moore, The Case of an Independent Political Action Committee, in PARTIEs, INterest Groups, and Campaign Finance Laws 56 (M. Malbin ed. 1980); Federal Election Campaign Act Amendments, 1979: Hearings Before the Senate Comm. on Rules \& Administralion, 96th Cong., 1st Sess. 159-61 (1979) (statement of Mary Mcehan) [hereinafter cited as Hearings on 1979 Amendments].

5. The amendments have not provided an adequate remedy for the procedural shortcomings of the 1976 statute. Wadlow, Election Law Reform Fails to Silence Critics, Legal Times of Washington, Dec. 3, 1979, at 5, col. I; letter from Paul D. Kamenar, practicing attorney, Feb. 3, 1980; interview with John Bolton, practicing attorney, in New Haven, Ct. (Oct. 23, 1979). 
violate the two principles of "First Amendment due process": promotion of accurate determinations and avoidance of unnecessary defense costs. After analyzing the FEC's previous enforcement procedures and the recent amendments in light of the First Amendment's procedural requirements, the Note proposes changes to create a constitutionally adequate enforcement procedure.

\section{The Federal Election Commission and Its Hybrid Enforcement Procedure}

The FEC is an independent agency within the executive branch, headed by six appointed commissioners, ${ }^{7}$ with exclusive jurisdiction over civil enforcement of the federal election campaign finance laws. ${ }^{8}$ It enforces rules concerning reporting and record-keeping, ${ }^{0}$ campaign contribution limits, ${ }^{10}$ corporate and union political activities, ${ }^{11}$ and public financing of presidential campaigns. ${ }^{12}$ FEC enforcement decisions have become the predominant interpretive guide ${ }^{13}$ to the some-

6. See generally Monaghan, First Ainendment "Due Process," 83 Harv. L. REv. 518 (1970).

7. Commissioners are appointed by the President, with the advice and consent of the Senate, for six-year terms. 2 U.S.C.A. $\$ 437$ c(a)(1) (West Supp. 1980).

8. 2 U.S.C.A. $\$ 437 \mathrm{c}(\mathrm{b})(1)$ (West Supp. 1980). A complainant must seek redress through the FEC and, if the FEC refuses to act, must follow specific review procedures in the United States District Court for the District of Columbia. 2 U.S.C.A. $\$ 437 g(a)(8)$ (West Supp. 1980); see In re Federal Election Campaign Act Litigation, Fed. Election CampaigN Financing Guide (CCH) I 9088 (D.D.C. June 14, 1979) (construing substantially similar provision of 1976 Act, 2 U.S.C. $\$ 437 g(a)(9)$ (1976)).

9. 2 U.S.C.A. $\$ \$ 432(a)-(i), 433,434$ (West Supp. 1980).

10. 2 U.S.C. $\$ 441 a(a)(1976)$.

11. Id. $\$ \$ 441 \mathrm{~b}-441 \mathrm{c}(1976)$.

12. 26 U.S.C. $\$ \S 9001-9012,9031-9042$ (1976).

13. Although Congress established a procedure for seeking advisory opinions from the FEC on the legality of specific, intended courses of action, 2 U.S.C. $\$ 437 f$ (1976), as amended, 2 U.S.C.A. $\$ 437 f$ (West Supp. 1980), observers agree that the more difficult interpretive questions are generally now being decided through enforcement actions rather than through prospective rulings. Moore, supra note 4, at 60; interviews with: Thomas Harris, member, Federal Election Commission, in Washington, D.C. (May 22, 1979); William C. Oldaker, then General Counsel to FEC, in Washington, D.C. (May 25, 1979); see note 77 infra (inadequacy of advisory opinion procedure).

In addition, FEC enforcement action may be a jurisdictional prerequisite for challenges to FEC interpretations or to the constitutionality of campaign finance laws. See National Conservative Political Action Comm. v. FEC, Fed. Election Campaign Financing Guide (CCH) 99057 (D.D.C. Apr. 28, 1978), appeal docheted, No. 78-1543 (D.C. Cir. 1978) (attempted challenge to advisory opinion and regulation); Martin Tractor Co. v. FEC, 460 F. Supp. 1017, 1019-21 (D.D.C. 1978), appeal docketed, No. 78-2080 (D.C. Cir. 1978) (attempted challenge to constitutionality of sections of campaign finance act under expedited declaratory relief procedure rejected). Contra, Bread Political Action Comm. v. FEC, 591 F.2d 29, 31-36 (7th Cir. 1979) (political action committee may seek expedited declaratory relief in constitutional challenge to campaign statute). 
times unclear provisions of the law. ${ }^{14}$ Those decisions result from a hybrid of investigative, prosecutorial, and de facto adjudicative functions.

\section{A. FEC Enforcement Procedures}

Recently enacted amendments to the campaign finance laws have modified the FEC enforcement framework established in $1976 .{ }^{15}$ The Federal Election Campaign Act, however, continues to specify a fourstage enforcement procedure that involves initiation of an action, investigation, efforts at conciliation, and finally, possible litigation. Approval by four of the six commissioners is required to proceed from one stage to the next. ${ }^{16}$

The four stages generally proceed as follows:

1) Initiation: an enforcement action may arise either from a signed, notarized complaint by an individual or from information obtained by the FEC from disclosure reports, audits, or other internal sources. ${ }^{17}$ When the Commission receives a complaint from outside the agency, it is required to notify the respondent and allow him fifteen days to "demonstrate, in writing, to the Commission ... that no action should be taken" against him on the basis of the complaint. ${ }^{18}$ If the Commission then votes, upon staff recommendation, to find "reason to believe" that a violation has occurred, it authorizes an investigation. ${ }^{19}$

2) Investigation: notification of a "reason to believe" finding must set forth the factual basis of the allegations; if the finding arose from internal sources, the respondent must be sent a copy of the staff

14. Grey areas include the dividing line between "independent expenditures," which may be unlimited in amount, and "in-kind contributions," subject to the contribution limits imposed by 2 U.S.C. $\$ 441 a(a)(1)$ (1976); the definition of "affiliation" between political committees, which subjects them to a single contribution limit, id. $\$ 441 \mathrm{la}(\mathrm{a})(5)$; and the criteria for "expressly advocating" the election or defeat of a candidate for federal office, which is defined as an "independent expenditure," 2 U.S.C.A. \$ 43I(17) (West Supp. 1980 ) (identical to 2 U.S.C. $\$ 431(\mathrm{p})(1976)$ ), and must be fully reported, 2 U.S.C.A. $\$ 434$ (West Supp. 1980); see Clagett \& Bolton, Buckley v. Valeo, Its Aftermath, and Its Prospects, 29 VAxD. L. Rev. 1327, 1353-54 (1976) (discussion of vagueness and complexity of the law).

15. See note 3 supra.

16. 2 U.S.C.A. $\$ 437 \mathrm{~g}(\mathrm{a})(2), \S 437 \mathrm{~g}(\mathrm{a})(4)(\mathrm{A})(\mathrm{i}), \S 437 \mathrm{~g}(\mathrm{a})(6)(\mathrm{A})$ (West Supp. 1980).

17. Id. $\$ 437 \mathrm{~g}(\mathrm{a})(1)-(2)$. Each new enforcement case is assigned a Matter Under Review (MUR) number, which serves as a file reference number. This Note will cite the MUR number when referring to material in the FEC's enforcement files.

18. Id. $\$ 437 \mathrm{~g}(\mathrm{a})(1) ; 45$ Fed. Reg. 15080,15121 (1980) (to be codified in 11 C.F.R. $\$ 111.6)$.

19. Id. $\$ 437 \mathrm{~g}(\mathrm{a})(2) ; 45$ Fed. Reg. 15080, 15121 (1980) (to be codified in 11 G.F.R. $\$ 111.7-.10$ ). 
report. ${ }^{20}$ The staff's investigation may include written questions, depositions, audits, and field investigations. ${ }^{21}$

After the investigation, the Commission decides whether to dismiss the case or to take further action. The 1976 statute did not provide the respondent, at this stage, with notice of the staff's contentions or an opportunity to present arguments to the Commission. ${ }^{22}$ Under the 1979 amendments, if the staff decides to recommend further proceedings, the respondent receives a brief stating the staff's position on the legal and factual issues of the case. The respondent is allowed fifteen days in which to submit a reply brief for consideration by the Commission before it votes whether to enter into conciliation. ${ }^{23}$

3) Conciliation: if the Commission finds "probable cause to believe" that a violation has occurred or is about to occur," it must attempt first "to correct or prevent such violation by informal methods of conference, conciliation, and persuasion, and to enter into a conciliation agreement with any person involved." 25 The agreement, negotiated by the staff and then approved by the Commission, may impose a civil penalty. Its terms are not subject to judicial scrutiny and it acts as a complete bar to further action by the Commission against the respondent for the particular violation. ${ }^{26}$

4) Litigation: if the Commission and respondent fail to reach a conciliation agreement, the Commission may vote to bring a civil action in federal district court. It must prove its allegations in a de novo trial. ${ }^{2 \tau}$

20. Id. $\S 437 g(a)(2) ; 45$ Fed. Reg. 15080,15121 (1980) (to be codified in 11 C.F.R. \$ I11.8(b), § 111.9); H.R. REP. No. 422, 96th Cong., Ist Sess. 21 (1979).

21. Id. $\S 437 \mathrm{~g}(\mathrm{a})(2) ; \S 437 \mathrm{~d}(\mathrm{a})(1)-(4) ; 45 \mathrm{Fed}$. Reg. 15080, 15121-22 (1980) (to be codified in 11 C.F.R. $\$ 111.10-.15)$.

22. 2 U.S.C. $\$ 437 g(a)(5)(A)$ (1976); 11 C.F.R. $\$ 111.6$ (1977); Oldaker, The Federal Election Commission: Enforcement Functions, in THE CoRPoration in Politics 1979, at 11, 15 (Practising Law Institute Course Handbook Series No. 296, 1979).

23. 2 U.S.C.A. $\$ 437 g(a)(3)$ (West Supp. 1980); 45 Fed. Reg. 15080, 15122 (1980) (to be codified in 11 C.F.R. $\$ 111.16)$.

24. Id. $\$ 437 \mathrm{~g}(\mathrm{a})(4)(\mathrm{A})(\mathrm{i}) ; 45$ Fed. Reg. 15080,15122 (1980) (to be codified in 11 C.F.R. $\$ 111.17(a))$. Under the 1976 statute, this determination was labeled "reasonable cause to believe" that a violation had occurred or was about to occur. 2 U.S.C. $\$ 437 g(a)(5)(A)$ (1976). This Note will refer to this vote as "decision to conciliate" or "entry into conciliation."

25. Conciliation efforts must occur for a period of at least 30 and not more than 90 days. 2 U.S.C.A. $\$ 437 g(a)(4)(A)(i)$ (West Supp. 1980); 45 Fed. Reg. 15080, 15122 (1980) (to be codified in 11 C.F.R. $\$ 111.18)$.

26. 2 U.S.C.A. $\$ 437 \mathrm{~g}(\mathrm{a})(4)(\mathrm{A})(\mathrm{i})$ (West Supp. 1980). The penalty accompanying a conciliation agreement is limited to the greater of $\$ 5,000$ or the amount involved in the violation, unless the violation is "knowing and willful," in which case the limits are doubled. Id. $\$ 437 \mathrm{~g}(\mathrm{a})(\mathrm{5})(\mathrm{A})-(\mathrm{B})$.

27. Id. $\S 437 \mathrm{~g}(\mathrm{a})(6) ; 45$ Fed. Reg. 15080,15123 (1980) (to be codified in 11 C.F.R. $\$ 111.19)$; interviews with: Oldaker, supra note 13; Barbara Van Gelder, executive as. sistant to Commissioner John McGarry and former FEC staff attorney, in Washington, D.C. (April 23, 1979) (expressing personal rather than official views). 


\section{B. The FEC's Misconception of Its Functions}

The FEC contends that it exercises only investigative and prosecutorial powers, because it has no formal authority to compel a party to enter into a conciliation agreement, admit a violation, or pay a fine..28 FEC officials have argued that the agency is analogous to a "civil grand jury" that has power only to bring its charges to the attention of a federal court for authoritative determination. ${ }^{29}$ If a respondent is dissatisfied with the Commission's position, they reason, he may refuse to sign a conciliation agreement and have the full procedural safeguards of a trial. ${ }^{30}$

Overemphasizing formal authority, this argument misconceives the agency's enforcement role. The four enforcement stages in fact constitute a hybrid of investigative, prosecutorial, and de facto adjudicative functions. The FEC plays an investigative role in the initial stages and a prosecutorial role in litigation. However, the FEC's grand jury analogy ignores its de facto power to adjudicate-to reach final dispositions of individual cases and to impose penalties without court reviewwhen cases are resolved without litigation. ${ }^{31}$

28. See Hearings on 1979 Amendments, supra note 4, at 150-51 (FEC's responses to committee questions) (FEC has no adjudicatory powers, only investigatory authority); FEC Record, March 1978, at 6, quoting FEC Memorandum of Points \& Authorities in Support of Motion to Dismiss at 15-17, in National Right to Work Comm. v. FEC, No. 78.0315 (D.D.C., filed Oct. 20, 1977) (FEC does not adjudicate, determine liability, or impose any legal sanctions on its own); FEC's Answers to Interrogatories of Defendants The Spotlight and Liberty Lobby at 2-3, in FEC v. The Spotlight, No. 78-1544 (D.D.C., filed Aug. 17, 1978) (Commission reaches no legal conclusions, does not determine liability of any party, or determine whether statute has been violated); interviews with: Joan Aikens, member, Federal Election Commission, in Washington, D.C. (May 22, 1979); Van Gelder, supra note 27.

29. Interview with Oldaker, supra note 13; see interview with attorney for respondent, by telephone (April 26, 1979) (describing FEC view).

30. Interview with Van Gelder, supra note 27; cf. FEC Memorandum of Points and Authorities at 3, National Right to Work Comm. v. FEC, No. 78-0315 (D.D.C., filed Oct. 20,1977 ) (administrative procedures merely preliminary to judicial trial).

The Act's enforcement sections are modeled after procedures of the Equal Employment Opportunity Commission (EEOC), which the FEC cites as precedent. See, e.g., FEC Memorandum in Opposition to Motion to Dismiss at 6.8, FEC v. Elias, No. 78-1922 (E.D. Pa., consent judgment filed April 18, 1979) (citing EEOC enforcement cases). The EEOC, however, does not regulate political expression or operate under the time and publicity pressures of the FEC. The practical opportunity for court review may therefore differ in the two agencies' proceedings, a factor affecting due process analysis. Cf. Boddie v. Connecticut, 401 U.S. 37I, 379-80 (1971) (practical obstacles to court review may deprive a party of due process right to hearing).

31. The Supreme Court has used the grand jury analogy for the investigative and prosecutorial roles of administrative agencies. See Ewing v. Mytinger \& Casselbery; Inc., 339 U.S. 594, 599 (1950) (agency, like grand jury, need not hold hearing before taking prosecutorial action); United States v. Morton Salt Co., 338 U.S. 632, 642 (1950) (FTC, like grand jury, may seck information without probable cause to suspect violation). However, the analogy is inappropriate when an agency imposes civil penalties and admissions of violation. A grand jury cannot accept a suspect's admission of guilt and payment of 
The FEC's quasi-adjudicative role commences at the end of the investigative stage, whenever the staff recommends entry into conciliation negotiations. The proceeding then becomes adversarial: the staff's position in favor of further enforcement stands directly opposed to the respondent's interests, and the Commission chooses between the two positions. ${ }^{32}$ A dismissal at the close of the investigation is the respondent's only way to avoid the expense and politically damaging publicity resulting from a conciliation agreement or a civil lawsuit. ${ }^{33}$

Conciliation, too, has elements of adjudication. The conciliation process is designed to avoid time-consuming litigation by resolving cases within the agency whenever possible. ${ }^{3 t}$ Although the FEC does not formally adjudicate, it may with respondent's consent-and without further review by a court or other adjudicative body-levy a civil penalty and record a formal declaration that the respondent has violated the law. ${ }^{35}$

Although legally voluntary, such agreements may be based upon the illusion of consent. Even if the respondent disagrees with the Commission's determination that he has violated the law, the exceptional economic and political pressures, and the time constraints of the campaign setting, may make a conciliation agreement the only realistic

a fine; a prosecutor may enter into a plea bargain but must secure the court's approval. Uniform Rule of Criminal Procedure 443(b); Fed. R. Crim. P. 11(c)-(c). In contrast, the FEC, like a court, has the power to give final approval to consent-type agreements. Moreover, the FEC lacks two characteristics that justify the grand jury's denial of additional procedural safeguards. First, the FEC does not share the grand jury's traditional role as an instrument of justice and protector of individuals. Costello v. United States, 350 U.S. 359, 362 (1956). Second, the FEC is required by law to make public the results of its enforcement decisions and the basis therefor. 2 U.S.C.A. $\$ 437 \mathrm{~g}(\mathrm{a})(4)$ (B)(ii) (West Supp. 1980); 45 Fed. Reg. 15080, 15123 (1980) (to be codified in 11 C.F.R. $\$ 111.20$ ).

32. Letter from Ronald D. Eastman, Washington, D.C., attorney for respondents in several MUUR's (July 3, 1979); letter from Peter Secchia, respondent in MUR 321 (June 8, 1979); interview with Jan Baran, then executive assistant to Commissioner Joan Aikens, by telephone (April 18, 1979); cf. 125 CoNG. Rec. S10,521 (daily ed. July 25, 1979) (remarks of Sen. Laxalt) (FEC has judicial as well as executive and legislative functions).

33. Except in non-filer cases, which involve failures to file disclosure reports, generally by marginal candidates and committees, and are handled in a separate procedure, the Commission has a policy of bringing a civil action if conciliation is unsuccessful. It rarely departs from this policy. The commissioners feel that dropping cases after the failure of conciliation would damage the Commission's credibility in conciliation and reduce the likelihood of agreements. Interviews with: Aikens, supra note 28; Harris, supra note 13; Robert Tiernan, member, Federal Election Commission, in Washington, D.C. (May 23, 1979).

34. H.R. ReP. No. 9I7, 94th Cong., 2d Sess. 4 (1976); 122 Cong. Rec. 12,199 (1976) (remarks of Rep. Wayne Hays). The FEC shares this interpretation of the statute. Motion of FEC to Dismiss at 6, Hampton v. FEC, Fed. Election Campaign Financing Guide (CCH) I 9036 (D.D.C. April 15, 1977), aff'd, No. 77.1546 (D.C. Cir. July 21, 1978).

35. 2 U.S.C.A. $\$ 437 \mathrm{~g}(\mathrm{a})(4)$ (A)(i) (West Supp. 1980). For a discussion of language used in conciliation agreements, see pp. 1213-14 infra. 
choice. ${ }^{36}$ Accepting an agreement on the FEC's terms may entail the political burden of admitting a violation, ceasing the activities in question, and undertaking in broad, vague terms not to engage in future violations. On the other hand, it brings enforcement proceedings to a close $^{37}$ and avoids the further publicity and expense of a lawsuit. The stakes or the respondent's resources may be too small to justify litigation. ${ }^{38}$ Because of these pressures, the Commission has reached agreements in most cases in which it has entered into conciliation. ${ }^{39}$

36. Of the 73 MUR's leading to conciliation agreements between May 1976 and May 1979,21 involved genuine disputes of fact or law. Only two of these assessed fines of $\$ 5,000$ or more; another resulted in a fine between $\$ 1,000$ and $\$ 5,000$. In ten of the MUR's, the agreements required no fines, but respondents continued to disagree with the FEC on the meaning of the statute. The remainder resulted in fines ranging from $\$ 100$ to $\$ 1000$. In purely economic terms, avoiding fines of this magnitude cannot justify litigation. Nearly one-third of the questionnaires answered by respondents who signed conciliation agreements indicated that the cost of litigation was the major factor in the respondents" decision not to fight the Commission any further. E.g., MUR 321 ("My attorney thought that we could beat them if we went higher, but we spent $\$ 12,000$ in legal fees (non-deductible-personal expense) and finally gave up."); MUR 372 ("We felt, and still feel, that [our] position was factually and legally correct. However, by refusing conciliation, the SEC [sic] would have been forced to initiate an enforcement action. The cost of that litigation would have been enormous.")

Many political participants and observers emphasized the cost of litigation and its effect on conciliation. Comment by Walter Moore, former executive assistant to Commissioner Neil Staebler, at Political Finance Forum, Washington, D.C. (May 24, 1979); interviews with: John Bolton, attorney for respondents in several MUR's, in Washington, D.C. (May 25, 1979); Joel Gora, ACLU, attorney for respondents in FEC litigation, by telephone (May 9, 1979); Mary Meehan, Treasurer, Committee for a Constitutional Presidency, by telephone (April 9, 1979); attomey for respondents, by telephone (April 16, 1979); labor union counsel, by telephone (April 18, 1979).

37. The General Counsel's letter notifying respondents of a "reason to believe" finding and enclosing a proposed conciliation agreement makes clear that the Commission will litigate if conciliation fails. After conciliation has proceeded for some time without results, the Commission may take the formal step of voting to authorize a lawsuit in order to put additional pressure on the respondent. Interview with Baran, supra note 32.

38. The FEC's situation is exceptional because it regulates participants in the political process; time constraints during campaigns, the dangers of adverse publicity, and limited resources combine to exert tremendous pressure upon respondents to conciliate, especially if the threatened civil penalty is nominal.

The general problem of pressure to settle enforcement proceedings to avoid litigation has been recognized in other contexts. $1 \mathrm{~K}$. Davis, Admisistrative LAw Treatise $\$ \S 4.05$, 4.06 (1st ed. 1958) (consent to administrative penalties is often coerced, yet agency decision is largely unprotected by procedural safeguards and may be arbitrary); Schmeltzer \& Kitzes, Administrative Civil Penallies Are Here To Stay-But How Should They Be Implemented? 26 AM. U.L. REv. 847, 852-53, 870 (1977) ("[w] here the fine is small, the respondent's constitutional rights may be sacrificed to economic practicality"; "arm twisting" to arrive at quick settlement); cf. Note, Costs and the Plea Bargaining Process: Reducing the Price of Justice to the Nonindigent Defendant, 89 YALE L.J. 333, 342-49 (1979) (heavy costs of criminal defense at trial put unreasonable pressure on nonindigent defendants to accept plea bargains).

39. In the nearly 500 MUR files opened after May 1976 and closed before the end of May 1979, the Commission decided to enter into conciliation in 99 MUR's (excluding 
In practice, therefore, the FEC occupies an intermediate position between quasi-judicial and purely executive agencies. The former are empowered to conduct full-scale adjudication on the record, subject to judicial review, whereas the latter must bring all enforcement cases in federal district court. ${ }^{40}$

The FEG's intermediate, hybrid model provides appropriate procedures for two categories of enforcement cases. Conciliation works fairly well for small cases involving clear-cut violations. ${ }^{41}$ Without imposing the expenses of a full-scale adjudicative proceeding, ${ }^{42}$ it allows the FEC to enforce the law and create incentives for compliance. ${ }^{43}$ Civil prosecution in federal court, on the other hand, is appropriate for

"non-filer" cases). Conciliation agreements were reached in 73 of these MUR's, nearly $75 \%$ of the cases. Civil actions were brought by the Commission in 18 MUR's, fewer than one-fifth of the cases that entered conciliation, and 8 other MUR's were dropped. Hence, conciliation agreements were four times as frequent as civil litigation.

40. The National Labor Relations Board is an example of the first model, 29 U.S.C. $\$ 160$ (1976); administrative agencies that enforce statutes through court adjudication, such as the Food and Drug Administration, 21 U.S.C. $\$ \$ 332-334$ (1976), represent the second. An intermediate model partly analogous to the FEC has been used in a number of federal regulatory schemes in which the statute sets forth guidelines for the amount of the penalty, the agency is authorized to mitigate or compromise the penalty by accepting payment of a lesser sum, but if negotiation fails, the agency must seck enforcement de novo in federal district court. No procedural guidelines are established for these internal agency determinations. See, e.g., 47 U.S.C. $\$ \$ 503,504$ (a)-(b) (1976) (FCC forfeitures for illegal rebates). See generally Schmeltzer \& Kitzes, supra note 38, at 851-56 (informal agency procedures for settling civil penalties). The perceived procedural inadequacies of this intermediate model have given rise to considerable discussion, but suggested changes remain locked within the traditional two-model concept. See, e.g., Goldschmid, Report in Support of Recommendation 72-6: An Evaluation of the Present and Potential Use of Civil Money Penalties as a Sanction by Federal Administrative Agencies, in 2 Recommendations and Reports of the Administrative Conference of the United States 896, 925-32 (1972) (recommending internal agency imposition of civil penalties after eridentiary hearings, as efficient alternative to federal court adjudication).

41. Of 73 MUR's leading to conciliation agreements, 52 MUR's involved clear fact situations and clear statutory provisions, most commonly corporate campaign contributions, and donations or loans in excess of the contribution limits. Thus, more than 70\% of these MUR's were appropriately handled by a simple, expeditious procedure. Cf. Goldschmid, supra note 40, at 932 (administrative imposition of civil penalties appropriate when volume of cases is large and legal issues rarely arise); Developments in the Law-Employment Discrimination and Title VII of the Civil Rights Act of 1967, 84 H.Anv. L. REv. 1109, 1200 (1971) (advantages of conciliation in employment discrimination cases).

42. Amendments proposing the application of Administrative Procedure Act requirements to the FEC and the establishment of hearing examiners were specifically rejected by the Committee on House Administration as overly expensive and unnecessary. Transcript of markup session, Committee on House Administration, March 9, 1978, at 499.50J (unpublished, on file at Committee).

43. See Schmeltzer \& Kitzes, supra note 38 , at 852 (since majority of administrative civil penalties "involve sums of less than $\$ 1,000$, lengthy legal procedures to assure compliance would be wasteful"); cf. Gellhorn, Administrative Prescription and Imposition of Penalties, 1970 WASH. U.L.Q. 265, 281 (administrative imposition of penalties " 'offers a lever to secure compliance with the law which the more ponderous instrument of court action could not afford" "). 
cases involving substantial issues of fact or law, unresolved First Amendment issues, and sizable amounts in controversy-a relatively small fraction of enforcement cases. ${ }^{44}$ Judicial proceedings are better able to deal with extensive, complex factual disputes than is the FEC's administrative process, ${ }^{45}$ and courts are more likely to bring a broad perspective to the First Amendment questions implicated in restrictions on political activity. ${ }^{46}$

More than one quarter of the conciliation agreements, however, involve issues that are too complex and controversial to be dealt with fairly under the current simplified procedures, but that are unlikely to reach court because the financial and political stakes are too small relative to the respondent's resources. ${ }^{47}$ If the respondent in such a case cannot persuade the agency to dismiss its action, he will be forced to enter into a conciliation agreement without sufficient safeguards for his rights.

\section{The FEC's Procedural Shortcomings}

Four flaws in the FEC enforcement process create the likelihood of unfairness to respondents in many cases. In each instance, FEC officials have denied the problem of unfairness and opposed new safeguards as too costly.

\section{A. Insufficient Disclosure of Information to Respondents}

In an adversarial proceeding, the respondent should know the basis of the allegations against him. The FEC's proceedings become adversarial when the staff recommends, at the close of investigation, that the Commission enter into conciliation rather than dismiss the case.48 If the Commission accepts the staff's recommendation, the respondent

44. Cases of this magnitude, pending or recently decided in federal district court, include FEC v. National Educ. Ass'n, 457 F. Supp. 1102 (D.D.C. 1978), appeal docketed, No. $79-1077$ (D.C. Cir. Jan. 22, 1979) (union political action committee's reverse checkoff procedure violates prohibition on coercive solicitation); FEC v. AFL-CIO, No. 77-2147 (D.D.C., summary judgment for plaintiff granted, June 16, 1978), appeal docketed, No. 78-1937 (D.C. Cir. Aug. 15, 1978) (\$300,000 transfer from AFL-CIO treasury to affiliated political action committee for loan repayment illegally commingled treasury and committee funds); FEC v. National Right to Work Comm., No. 77-2175 (D.D.C., filed Dec. 21, 1977) (solicitation of contributions from more than one million "members" of incorporated ideological organization; FEC charges violation of ban on soliciting funds from general public).

45. The FEC, an agency without hearing examiners, is not structured to adjudicate factual disputes. Interview with Van Gelder, supra note 27; cf. interview with Gora, supra note 36 (FEC insists it is unable to find facts and develop formal record).

46. Monaghan, supra note 6, at 522-24; cf. interview with Oldaker, supra note 13.

47. See note 36 supra.

48. See p. 1204 supra. 
must choose between the burdensome alternatives of a conciliation agreement or litigation. ${ }^{49}$ Yet at this stage, the FEC does not give the respondent sufficient access to the staff's information and evidence to allow effective rebuttal.

The 1979 amendments provide that, if the staff recommends entry into conciliation, the respondent shall receive a brief setting forth the law and facts supporting the staff's position and shall have fifteen days in which to submit a reply brief before the Commission decides on the staff's recommendation. ${ }^{50}$ Although this is a substantial improvement over the prior practice,,$" 11$ the respondent still is denied access to the documents, correspondence, interrogatories, deposition transcripts, and audit workpapers that support the staff's view of the facts. Such access is essential for effective rebuttal by the respondent, 52 because the staff may have acquired material that is incomplete, erroneous, or unfamiliar to the respondent. ${ }^{53}$

49. See note 33 supra.

50. 2 U.S.C.A. $\$ 437 \mathrm{~g}(\mathrm{a})(3)$ (West Supp. 1980); 45 Fed. Reg. 15080, 15122 (1980) (to be codified in 11 C.F.R. $\$ 111.16$ ).

51. By contrast, under the 1976 legislation the staff did not even inform the respondent that it was about to recommend conciliation and refused to give the respondent a copy of its report to the Commission. Interviews with attorneys for respondents in FEC enforcement cases, including: Bolton, supra note 36; Gora, supra note 36; Paul Kamenar, attorney for defendants in several FEC civil enforcement actions, by telephone (April 26, 1979).

52. Interview with Bolton, stupra note 36. On a number of occasions, respondents' attorneys have asked not only for a copy of the staff report but also for access to evidentiary materials gathered during the investigation. E.g., MUR 384, General Counsel's Report, March 22, 1978, at 2 (referring to respondent's Motion for Leave to Review Evidence Obtained Through Investigation); MUR 236/266, letter from Donald W. Fisher, attorney for respondent, to David Spiegel, FEC staff attorney (Oct. 11, 1977) (requesting notice of depositions and opportunity to attend); FEC's Answers to Interrogatories of Defendant The Spotlight at 4, FEC v. The Spotlight, No. 78-1544 (D.D.C., filed Aug. 17, 1978) (asking for detailed descriptions or disclosure of documents regarding Commission enforcement proceedings against respondent).

In several administrative contexts, courts have recognized the dangers of unfairness if the respondent may not rebut material on which the agency bases its decision. E.g., Shively v. Stewart, 65 Cal. 2d 475, 479-80, 421 P.2d 65, 68, 55 Cal. Rptr. 217, 220 (1966) (in disciplinary proceeding, licensed physicians may obtain discovery of information held by agency to permit full opportunity to prepare defense); Mazza v. Cavicchia, 15 N.J. 498 . 515-16, 105 A.2d 545, 555 (1954) (agency head may not use hearing examiner's report unless report is disclosed to litigant, permitting rebuttal of erroneous conclusions or factual blunders); cf. Schwartz, Instilutional Administrative Decisions and the Morgan Cases: $A$ Re-examination, 4 J. PuB. L. 49, 88 (1955) (agency should disclose staff memorandums to private parties and permit filing of execptions). Although recognizing that the Frecdom of Information Act is not a substitute for discovery in agency adjudicative procecdings, courts have acknowledged the criticism that refusing to allow respondents access to agency factual materials amounts to "trial by ambush." New England Medical Center Hosp. v. NLRB, 548 F.2d 377, 387 (1st Cir. 1976); Capital Cities Communications, Inc. v. NLRB, 409 F. Supp. 971,977 (N.D. Cal. 1976).

53. Bolton, supra note 4, at 50; interviews with: attorney for respondent, supra note 29; attorney for respondents, supra note 36. 
The FEC staff has resisted disclosure of information to respondents on the grounds that files must remain secret to assure effective investigations, ${ }^{54}$ that staff reports are protected by the work-product privilege, ${ }^{, 5}$ and that the Federal Election Campaign Act guarantees the confidentiality of investigations. ${ }^{50}$ They argue further that disclosure of their material would aid the defense and that respondents' attorneys should do their own work..$^{57}$

These arguments are unconvincing. At the threshold of conciliation, the staff report and supporting evidentiary materials are more closely analogous to the brief and exhibits of one of the contending parties in an adjudicative proceeding than to internal, privileged records. ${ }^{58}$ Thus, the policy reasons for recognizing the investigative-files or work-product privileges are absent. ${ }^{59}$ The statutory guarantee of confidentiality is designed to protect the respondent from prejudicial and unverified disclosures, ${ }^{60}$ not to hide information from him. Finally, the FEC should not object to facilitating the respondent's defense; its role is not to penalize as many respondents as possible but to enforce the election laws fairly. Thus, the FEC's withholding of evidentiary in-

54. Interview with Oldaker, supra note 13. Under the investigatory records exemption of the Freedom of Information Act (FOIA), 5 U.S.C. $\$ 552(b)(7)$ (1976), materials may be withleld if their disclosure would interfere with enforcement proceedings, prevent a fair trial or impartial adjudication, violate personal privacy, disclose confidential sources or investigative techniques, or endanger law enforcement personnel. See generally New England Medical Center Hosp. v. NLRB, 548 F.2d 377 (1st Cir. 1976) (denial of FOIA request upheld on basis of investigatory records exemption); $1 \mathrm{~K}$. Davis, ADMinistrative Liw Treatise $\$ 5: 39$ (2d ed. 1978) (discussion of investigatory records exemption).

55. Interview with Van Gelder, supra note 27. The work-product privilege, developed in the context of civil litigation, Hickman v. Taylor; 329 U.S. 495, 509-14 (1947); FED. R. Giv. P. 26(b)(3), also has been applied in the administrative context. National Courier Ass'n v. Board of Govs. of Fed. Rescrve Sys., 516 F.2d 1229, $1241-42$ (D.C. Cir. 1975) (privilege protects internal memorandums embodying deliberative processes of agency and staff).

Recently, in a complainant's suit against the FEC for failing to act promptly on the complaint, the court stated in dictum that the work-product privilege precluded access by the respondent to FEC investigative records during investigation. Common Cause v. FEC, Fed. Election Campaign Financing Guide (CCH) 9089 at n.6 (D.D.C. Aug. 10, 1979).

56. 2 U.S.C.A. $\$ 437 \mathrm{~g}(\mathrm{a})(12)$ (West Supp. 1980); 45 Fed. Reg. 15080, 15123 (1980) (to be codified in 11 C.F.R. $\$ 111.21$ ).

57. Interviews with: Oldaker, supra note 13; Van Gelder, supra note 27.

58. See p. 1204 supra.

59. The investigative-files and work-product doctrines protect the parties' ability to assemble material into a coherent whole before exposing it to outside scrutiny. See Hickman v. Taylor, 329 U.S. 495, 510-11 (1947). At the decisionmaking stage, however, they do not deprive the defendant of access to the evidence suporting the prosecution's case. At either an administrative hearing or a trial, the decision must be made solely on the basis of evidence entered formally into the record and thus revealed to the defendant.

60. A notification of violation or investigation may be disclosed by the FEC if the respondent gives written consent. 2 U.S.C.A. $\$ 437 \mathrm{~g}(\mathrm{a})(12)(\mathrm{A})$ (West Supp. 1980); 45 Fed. Reg. 15080,15129 (1980) (to be codified in 11 C.F.R. $\$ 111.21$ ). 
formation at the pivotal "probable cause to believe" stage is unjustified.

\section{B. Insufficient Right of Reply}

Along with inadequate access to information, respondents are permitted insufficient opportunity to argue before the commissioners, thus giving the agency staff disproportionate influence over Commission decisionmaking. ${ }^{61}$ Although respondents may submit written briefs, they have no right to oral argument. Once the briefs have been submitted, the Commission can reach enforcement decisions in closed sessions at which the General Counsel and staff attorneys support the staff report. The respondent has no similar opportunity to present his case in person and to answer questions. ${ }^{62}$

Commissioners and staff have opposed oral argument, contending that respondents' written submissions and the staff report give the Commission a fair and effective presentation of the respondents' position, ${ }^{63}$ and that oral argument would be excessively costly and time-consuming. ${ }^{64}$ Oral arguments, however, can force a decisionmaker to focus

61. Before the 1979 amendments, the FEC did not inform respondents of the staff's contentions and was not statutorily required to consider respondents' arguments at the preconciliation stage. Interviews with: Bolton, supra note 36; Gora, supra note 36; Kamenar, supra note 51 ; Walter Moore, former executive assistant to Commissioner Neil Staebler, by telephone (April 16, 1979); Loren Smith, attorney in MUR 406, by telephone (April 30, 1979). Respondents' positions were presented to the Commission primarily through the staff report, which sometimes presented an incomplete or inaccurate account. Interviews with: Bolton, supra note 36; Kamenar, supra note 51.

62. See FEC's Answers to Interrogatories, supra note 28, at 6; Moore, supra note 4, at 60; interviews with: Bolton, supra note 36; Moore, supra note 61; former attorney, Office of General Counsel, FEC, by telephone (April 30, 1979). A number of observers have noted the Commission's deference to its legal staff. Interviews with: Baran, supra note 32; James Schoener, former staff member, Senate Rules Committee, by telephone (April 23, 1979); former staff attorney, Office of General Counsel, FEC, by telephone (April 20, 1979).

From May 1976 to May 1979, the Commission followed the staff's recommendation on whether to dismiss or to enter into conciliation in 211 of the 219 MUR's in which it had authorized an investigation. Although some of these were clear-cut cases, others raised substantial factual and legal issues. Author's review of FEC enforcement files.

63. Interviews with: Baran, supra note 32; John G. Murphy, Jr., former General Counsel, FEC, in Washington, D.C. (May 24, 1979); Neil Staebler, former member, Federal Election Commission, by telephone (April 23, 1979); Van Gelder, supra note 27.

64. Hearings on 1979 Amendments, supra note 4, at 151; interviews with: Aikens, supra note 28; Baran, supra note 32; Tiernan, supra note 33; Van Gelder, supra note 27; executive assistant to FEC member, in Washington, D.C. (May 22, 1979).

General Counsel Oldaker asserted that, if respondents were allowed even a brief oral argument, every respondent who faced any risk of "civil or political penaltics" would demand an oral argument, resulting in hundreds of such hearings each year. Thus, he argued, providing a right to oral argument would entail the abandonment of the simplified, streamlined current procedure and the adoption of a full panoply of hearing examiners-which would cause much greater expense and delay for respondents and the Commission. Interview with Oldaker, supra note 13. 
on the central issues of a case and permit him to resolve uncertainties by asking questions. ${ }^{65}$ The FEC's cost argument is exaggerated. Because oral argument is expensive, respondents are unlikely to exercise the option unless they have grounds to believe that it would significantly strengthen their position. ${ }^{.6}$

\section{Failure to Provide a Statement of Reasons}

The Commission never states reasons for actions it has taken at the various procedural stages. After closing a case by dismissal, conciliation, or litigation, the FEC places the major documents relating to the case, including staff reports to the Commission, in a public file. ${ }^{67}$ However, the Commission adopts only the staff's recommendations, not its legal reasoning, ${ }^{68}$ with which the commissioners have sometimes disagreed. ${ }^{69}$

Failure to provide reasons for enforcement actions impairs the quality of the Commission's decisionmaking. The commissioners may decide on a course of action without majority agreement on an interpretation of the law or its application to the facts. This reduces the coherence and

65. Cf. E. RE, Brief Writing and Oral Argument 176 (4th ed. 1974) (argument clarifies positions in brief); Schmeltzer \& Kitzes, supra note 38 , at 870 (fairness would be enhanced by respondent's oral presentation to agency heads before imposition of civil penalties). Several commentators have pointed to these advantages in calling for oral argument before the FEC. Interviews with: Bolton, supra note 36; Thomas Curtis, former member, Federal Election Commission, by telephone (April 17, 1979); Gora, supra note 36; Smith, supra note 61 .

66. Counsel fees are the largest element in respondent's expenses for oral argument. Interviews with Baran, supva note 32; Bolton, supra note 36; cf. Scott, Standing in the Supreme Court-A Functional Analysis, 86 HARv. L. REv. 645, 673-74 (1973) (costs of litigation serve as substantial screening barrier and assure that plaintiffs will have adequate stake in outcome of controversy).

67. The statute requires public disclosure of conciliation agreements and dismissals of enforcement cases. 2 U.S.C.A. $\$ 437 \mathrm{~g}(\mathrm{a})(4)(\mathrm{B})(\mathrm{ii})$ (West Supp. 1980). These materials are available at the FEC's offices in Washington, D.C. In June 1979, the Commission began to publish summaries of selected closed compliance cases in its monthly newsletter, the FEC RECORD.

68. A certification of the Commission's votes recites that the Commission has voted to adopt the recommendations of the General Counsel's Report, not that it has voted to adopt the report. Author's review of FEC enforcement files; Plaintiff's Memorandum of Points and Authorities in Opposition to Defendant's Motion for Summary Judgment at 6, Brown v. FEC, No. 79-0940 (D.D.C., filed April 2, 1979).

69. See FEC RECORD, October 1979, at 4 ("Commission's actions are not necessarily based on, or in agreement with, the General Counsel's analysis."); interviews with: Baran, supra note 32; Harris, supra note 13; Moore, supra note 61; former FEG attorney, supra note 62.

The Commission occasionally adopts the General Counsel's Report as a statement of reasons. E.g., Motion of FEC to Dismiss for Failure to State a Claim at 9, Hampton v. FEC, Fed. Election Campaign Financing Guide (CCH) If 9036 (D.D.C., April 15, 1977), aff'd, No. 77-1546 (D.C. Cir. July 21, 1978) (General Counsel's statement of reasons was sufficient grounds for FEC's dismissal of complaint). 
predictability of enforcement decisions and deprives political participants of a guide to the Commission's interpretation of the law.:0

Commission sources argue that the need to seek agreement on reasons as well as on action-and to produce written opinions-would delay the disposition of cases, reduce the Commission's case-by-case flexibility, and burden the Commission and its staff. ${ }^{71}$ In addition, they contend that statements of reasons might mislead candidates and committees, because a changing body of six people is prone to change its policies. ${ }^{22}$ They maintain that the present procedure for obtaining advisory opinions $^{73}$ is sufficient to provide guidance in unclear areas of the law. ${ }^{74}$

But decisionmakers who cannot agree on the reasons for their determinations may reach arbitrary-if prompt-results. ${ }^{i 5}$ The FEC exaggerates the cost of a statement of reasons: additional time and effort would be required only when the commissioners do not agree with the rationale in the staff reports. ${ }^{\text {i }}$ Moreover, flexibility should not be purchased at the price of clarity. Legitimate variations in result can and should be explained; changes in policy should be announced and applied prospectively. Stating reasons for decisions would supplement the advisory opinion process as a needed guide to interpretation. ${ }^{77}$

70. Moore, supra note 4, at 61-62; interviews with: Bolton, supra note 36; Gora, supra note 36; Kamenar, supra note 51; Moore, supra note 61; Murphy, supra note 63; journalist, in Washington, D.C. (May 22, 1979).

71. Interviews with: Oldaker, supra note 13; executive assistant, supra note 64 .

72. Interview with Van Gelder, supra note 27. Commissioner Tiernan opposed the disclosure of Commission deliberations, even in closed cases, on the ground that respondents in other pending matters before the Commission would be able to use the information to shape their presentations to the Commission. Interview with Tiernan, supra note 33.

73. 2 U.S.C.A. $\$ 437$ f (West Supp. 1980).

74. Interviews with: executive assistant, supra note 64; FEC staff member, in Washington, D.C. (May 25, 1979).

75. 2 K. Davis, Administrative Law Treatise $\$ 16.00$, at 559-61, 564 (Supp. 1970); see Friendly, "Some Kind of Hearing," 123 U. PA. L. Rev. 1267, 1292 (1975).

76. In the majority of cases, the Commissioners could simply adopt the staff's statement of reasons. Interviews with: Harris, supra note 13; Staebler, supra note 63.

77. The advisory opinion procedure is inadequate. Although the 1979 amendments allow all persons-not only officeholders, candidates, political committees, and national party committees, as provided by the 1976 legislation-to seek advisory opinions with respect to a specific transaction or activity by the person, 2 U.S.C.A. $\$ 437 f(a)$ (West Supp. 1980), opinions cannot be issued in "hy pothetical" cases, no matter how detailed. 45 Fed. Reg. 15080, 15123 (1980) (to be collified in 11 C.F.R. \$ 112.I). A person secking an opinion must publicly commit himself to an intention to undertake the proposed activity. In the past, the slowness of the procedure has discouraged many political participants from seeking advisory opinions. Campaign Finance Study Group, Institute of Politics, Kennedy School of Gov't, Harvard Univ., for House Comm. on House Administration, 96rh Cong., Ist Sess., AN ANalysis of the Impact of the Federal Election Campaign ACT, 1972-78, at 139-41 (Comm. Print 1979); Moore, supra note 4, at 61-62. The amendments set a 60-day deadline for FEC action on advisory opinion requests, 20 days in the 60-day period before an election, 2 U.S.C.A. $\$ 437 f(a)$ (West Supp. 1980); 45 Fed. Reg. 15080, 


\section{Burdensome Conciliation Policy}

In addition to the FEC's insufficient disclosure to respondents, insufficient right of reply, and failure to provide a statement of reasonsthree strictly procedural matters-the FEC's policies regarding conciliation negotiations have provoked frequent complaints from respondents. Respondents perceive the FEG's approach to conciliation as an integral and unreasonable part of its burdensome enforcement procedure. ${ }^{78}$

The FEC enjoys a strong bargaining position in conciliation negotiations, because of the pressures on respondents to settle rather than litigate. ${ }^{70}$ Taking advantage of its position, the staff frequently plays the role of an advocate when it proposes conciliation terms, ${ }^{80}$ attempting to impose a view of the facts or the law that would be difficult to sustain in court, where it would bear the burden of proof. ${ }^{81}$ The Commission routinely demands a direct admission of violation at the outset of negotiations, ${ }^{82}$ agreeing to an indirect admission of violation or neutral

15124 (1980) (to be codified in 11 C.F.R. $\$ 112.4$ ). However, recognizing political reality, the legislative history expressly states that 3-3 Commission deadlocks, which have occurred in the past on party financing and labor/business issues, Moore, Comment, supra note 36, constitute Commission "action" in compliance with the 60-day limit. H.R. REP. No. 422, 96th Cong., Ist Sess. 20 (1979); see 45 Fed. Reg. 15080, 15124 (1980) (to be codified in 11 C.F.R. $\$ 112.4(\mathrm{a}))$.

78. See note 85 infra.

79. See note 36 supra.

80. Author's analysis of enforcement cases; see Defendants' Response to FEC's Motions at 4, FEC v. Bell, No. $79-1891$ (D.D.C., filed July 20, 1979); letter from Eastman, supra note 32; letter from Secchia, supra note 32; interview with Smith, supra note 61 .

81. Hearings on 1979 Amendments, supra note 4, at 160 (statement by Meehan); 125 Cong. Rec. S11,212-15 (daily ed. Aug. 1, 1979) (remarks of Sen. Humphrey); see, e.g., FEC v. Central Long Island Tax Reform Immediately (CLITRIM), No. 79-3014 (2d Cir. Feb. 5, 1980); FEC v. American Fed'n of State, County \& Mun. Employees, Fed. Election Campaign Financing Guide (CCH) 9078 (D.D.C. May 14, 1979).

82. Interviews with: Aikens, supra note 28; Baran, supra note 32; Staebler, supra note 63; attorney for respondents, supra note 29; exccutive assistant, supra note 64; former FEC attorney, supra note 62. Responses to questionnaires frequently noted a stated FEC policy of insisting on an admission of violation. General Counsel's Reports also referred to the crucial importance of an admission. E.g., MUUR's 218, 274, 515, 623 .

In some agreements, the respondent is required to promise not only that he will not repeat the activities in question, but that he will not violate broad provisions of the Federal Election Campaign Act or the entirc Act. Conciliation agreements on public file, FEC, Washington, D.C. These ill-defined promises may be enforced in federal district court by the FEC, which may obtain relief by establishing a violation, in whole or in part, of any requirement of the agrecment. 2 U.S.C.A. $\$ 437 \mathrm{~g}(\mathrm{a})(5)(\mathrm{D})$ (West Supp. 1980). As of December 1979, the FEC had brought two enforcement actions under this provision. Litigation Status Sheet, January 1980, Press Office, FEC; FEC RECond, December 1979, at 6. The possibility of such enforcement may exert an inhibiting effect on signers of conciliation agreements. Interview with Bolton, supra note 5; $c f$. O. Fiss, THe CiviL Rights INJUNCTION 13 (1978) (broad commands may deter, apart from penalty for violation, because costs are imposed on defendant by very assertion of claim of violation and necessity of defending enforcement proceeding). 
consent-decree language only after expensive and time-consuming negotiations. ${ }^{83}$

Yet the statute does not require the Commission to insist on an admission of violation in a conciliation agreement, and the acceptance of consent-decree language-which is frequently permitted by other administrative agencies ${ }^{84}$-would better serve the purposes of a "conciliation" process. ${ }^{85}$ In response to criticisms of its conciliation policy, the FEC contends that agreement is voluntary and that an admission of violation serves remedial purposes. ${ }^{s 0}$ But the FEC's rigid conciliation policy imposes excessive burdens on respondents, either by impelling them into costly litigation to seek vindication or by requiring them to accept the FEC's terms of conciliation when the pressures of time, money, or publicity preclude a judicial determination.

\section{First Amendment Due Process}

Unfair in practice, FEC procedures also are constitutionally defective. Under the First Amendment, procedural safeguards are required whenever the government regulates or burdens potentially protected

83. On average, MUR's leading to conciliation agreements lasted nearly 12 months from complaint to agreement. Twenty-one MUR's with complex, disputed issues of fact or law averaged more than 14 months. In eight of these MUR's the agreements included direct admissions of violation ("respondent violated Scction $\mathbf{X}$ of the Act"); in four others, they included indirect admissions ("Section $\mathrm{X}$ of the Act prohibits activity $\mathrm{Y}$; respondent did $\left.\mathrm{Y}^{\prime \prime}\right)$. In the disputed cases in which the respondent succeeded in avoiding any admission of violation, the enforcement process lasted an average of 18 months.

Commission sources acknowledge that the respondent is more likely to obtain favorable language after a lengthy conciliation process. Interviews with: Baran, supra note 32; Harris, supra note 13. Extended negotiations, however, impose considerable costs on respondents. More than half of the respondents who answered the author's questionnairc stated that the proceeding imposed a significant financial burden; comments referted most frequently to attorneys' fees. Approximately one-quarter of the questionnaires indicated leggal fees in excess of $\$ 1000$ for the conciliation process.

The amendments limit the Commission's attempts to conciliate to 90 days, 2 U.S.C.A. $\S 437 \mathrm{~g}(\mathrm{a})(4)(\mathrm{A})(\mathrm{i})$ (West Supp. 1980). To some extent, the amendments may increase the pressures on respondents to accept unsatisfactory terms before the Commission ceases to attempt conciliation.

84. E.g., Federal Trade Commission, 16 C.F.R. $\$ 3.25$ (1980); Securities and Exchange Commission, 17 C.F.R. $\$ 201.8(a)$ (1979).

85. Bolton, supra note 4, at 50; letter from Eastman, supra note 32; interview with Smith, supra note 61. The Commission's policy of demanding an admission of violation is a major obstacle to conciliation, causing delays and sometimes ultimate failure to reach agreement. Interviews with: Baran, supra note 32; Gora, supra note 36; Kamenar, supra note 51; Mcehan, supra note 36; Oldaker, supra note 13; former FEC staff member, by telephone (April 17, 1979).

86. Interviews with: Aikens, supra note 28; Harris, supra note 13 . The standard form for a conciliation agreement states that "respondent enters voluntarily into this conciliation agreement." Interviews and questionnaires indicate that this language is often pro forma and does not accurately reflect respondent's views. 
expression. ${ }^{87}$ Because of the high value placed on freedom of expression, these requirements are more stringent than conventional Fifth and Fourteenth Amendment due process guarantees for civil proceedings. ${ }^{88}$

The FEC's enforcement procedures fall directly within the ambit of the stricter standards. The FEC, by regulating contributions and expenditures that are indispensable to political communication, regulates "an area of the most fundamental First Amendment activities."s0 Although the FEC lacks the unilateral power to impose formal restraints and sanctions, a procedure's practical effects on the exercise of free expression also must meet First Amendment standards. The FEC's procedures fail to satisfy constitutional strictures.

\section{A. Unduly Burdensome Procedures: Two Criteria}

The First Amendment invalidates unduly burdensome procedures that deter protected expression. Two principles have emerged to define

87. First Amendment due process principles are most frequently enunciated in cases challenging state procedures for making obscenity determinations. See, e.g., Southeastern Promotions, Ltd. v. Conrad, 420 U.S. 546, 559-61 (1975) (exclusion of rock musical from municipal theater on grounds of alleged obscenity requires judicial determination); Freedman v. Maryland, 380 U.S. 51, 57-59 (1965) (censorship proceeding must assure prompt judicial review before final order). The principles also have been applied to the regulation of political activity, Carroll v. President \& Comm'rs of Princess Anne, 393 U.S. 175, 181-83 (1968) (injunction against disruptive political rallies requires adversary proceeding); Speiser v. Randall, 357 U.S. 513, 520-21, 525-26 (1958) (state has burden of proof in denying tax exemption for subversive advocacy), and to federal as well as state law, Blount $v$. Rizzi, 400 U.S. 410, 416-18 (1971) (denial of postal services to obscenity dealers requires prompt judicial proceedings). See generally Monaghan, supra note 6, at 518.

These procedural requirements apply without regard to the substantive validity of the regulations or burdens that the state imposes. Frequently, the Court has reached the procedural question first and declined to decide the substantive issue. E.g., Southeastern Promotions, Ltd. v. Conrad, 420 U.S. 546, 562 (1975); Speiser v. Randall, 357 U.S. 513, $519-20$ (1958).

88. Some procedures that satisfy conventional due process fail to satisfy the stricter standards of First Amendment due process. Marcus v. Search Warrant, 367 U.S. 717, 730-31 (1961) (procedures for seizure of gambling paraphernalia and contraband liquor insufficient for seizing allegedly obscene materials); Smith v. California, 361 U.S. 147, 150-53 (1959) (constitution requires scienter for bookseller's obscenity conviction, though not for most crimes); Monaghan, supra note 6 , at 518-19.

89. Buckley v. Valeo, 424 U.S. 1, 14 (1976). The Supreme Court has stated explicitly that, "[T] he constitutional guarantee has its fullest and most urgent application precisely to the conduct of campaigns for political office." Monitor Patriot Co. v. Roy, 401 U.S. 265, 271-72 (1971).

The need for procedural protection in the regulation of political activity may be greater than in the regulation of obscenity. See, e.g., Shuttlesworth v. City of Birmingham, 394 U.S. 147, 162-63 (1969) (Harlan, J., concurring) (procedural delay has more severe impact on civil rights demonstration than on exhibition of motion pictures); Carroll v. President \& Comm'rs of Princess Anne, 393 U.S. 175, 182 (1968) (notice and hearing more essential before forbidding political rally than before banning allegedly obscence books). 
an unconstitutional burden on expression. The first principle holds that a procedure must not create an undue likelihood that protected expression will be penalized..$^{00}$ Application of this principle, most frequently in obscenity cases, has generated several specific rules: the state must always bear the burden of proof; ${ }^{01}$ final restraints on speech may be imposed only by judicial determination in an adversary proceeding; ${ }^{22}$ preliminary restraints must be "limited to preservation of the status quo for the shortest fixed period compatible with sound judicial resolution." 33

The second principle of First Amendment due process is that a procedure must not unnecessarily impose heavy costs upon the defense of First Amendment rights. ${ }^{94}$ The prospect of a protracted, costly defense might induce self-censorship and thus chill protected speech. $.^{95} \mathrm{Al}-$ though this principle has not been stated as frequently or directly as the first principle, it emerges clearly from a number of First Amendment cases. The Supreme Court has invoked the principle in decisions preventing further prosecutions under facially unconstitutional statutes, by allowing a defendant who has engaged in unprotected activity to challenge the constitutionality of a statute that might otherwise be

90. See Speiser v. Randall, 357 U.S. 513, 525-26 (1958); note 87 supra (citing cases). In these cases, the Court focuses only upon the undue likelihood of erroneous determinations and does not explicitly consider whether that burden could be justified. Implicitly, it might be suggesting that since the state can achieve its objectives by a "Icss drastic means"-a procedure with more safeguards-it cannot justify the existing procedure.

91. Thus, expression will be protected from the risk of nonpersuasion. See Freedman v. Maryland, 380 U.S. 51,58 (1965); Speiser v. Randall, 357 U.S. 513, 526 (1958).

92. E.g., Blount v. Rizzi, 400 U.S. $410,417-18$ (1971) (statute must provide for judicial review); Carroll v. President \& Comm'rs of Princess Anne, 393 U.S. 175, 183 (1968) (judicial proceeding must be adversarial).

93. Freedman v. Maryland, 380 U.S. 51, 59, 61 (1965).

94. In Freedman, avoidance of "unduly expensive and protracted" litigation, id. at 61, was distinct from the likelihood of vindication in court. In every reported case, the Maryland Court of Appeals had reversed disapproval by the State Board of Censors. Id. at 58 n.4.

0

95. In a recent case, for instance, the Court recognized that an ill-defined prohibition against certain corporate political activities would deter protected expression by creating the threat of penalties. "In addition, the burden and expense of litigating the issueespecially when what must be established is a complex and amorphous economic relationship-would unduly impinge on the exercise of the constitutional right. '[T]he free dissemination of ideas [might] be the loser.' " First Nat'l Bank of Boston v. Bellotti, 435 U.S. 765, 785 n.21 (1978); accord, Rosenbloom v. Metromedia, Inc., 403 U.S. 29, 52-53 (1971) (plurality opinion) (possibility of expensive and protracted litigation sufficient threat to inhibit protected discussion).

As Professor Monaghan declares, "[I]n the area of freedom of speech the procedures associated with the penalty (e.g., arrest, pretrial detention, etc.) often discourage challenge to the underlying statute or ordinance far more than the penalty it contains." Monaghan, supra note 6, at $548 \mathrm{n.122;}$ cf. Note, The Role of Summary Judgment in Political Libel Cases, 52 S. Cal. L. REv. 1783, 1808-09 (1979) (expense of litigating libel actions may induce self-censorship by media, infringing First Amendment rights). 
used to prosecute protected expression, ${ }^{96}$ or by granting declaratory judgment that a statute is invalid. ${ }^{97}$ Recently, with the Court's approval, an enforcement procedure has been upheld against First Amendment challenge because proposed alternatives would impose even greater costs on defendants, thus increasing the chilling effect.98

Procedures for regulating First Amendment activity must strike a balance between these two principles. The rule requiring a judicial determination before any sanction can be imposed on protected activity illustrates the tension between the two principles. In Freedman $v$. Maryland ${ }^{90}$ the Supreme Court held that in order to satisfy the need for accurate determinations, only courts may legitimately impose restraints on expression, "because only a judicial determination in an adversary proceeding ensures the necessary sensitivity to freedom of expression." ${ }^{100}$ Yet, as applied to the FEC, this rule would be prohibitively

96. An essential element of the First Amendment "overbreadth doctrine" is the recognition that the threat of the "expense and inconvenience of criminal prosecution" will have an inhibiting effect on those "who validly exercise their rights of free expression." Smith v. California, 361 U.S. 147, 151 (1959).

97. See Zwickler v. Koota, 389 U.S. 241, 252 (1967) (granting declaratory judgment invalidating political pamphleting statute because delay accompanying criminal proceedings "might itself effect the impermissible chilling of the very constitutional right he seeks to protect"); Dombrowski v. Pfister, 380 U.S. 479 (1965) (granting declaratory and injunctive relief against prosecutions and threatened prosecutions for alleged violations of state subversive activities control laws by civil rights groups). In Dombrowski, appellants alleged that the threats of enforcement were made in bad faith as part of a plan of harassment. Despite the likelihood of acquittal in state courts, the Court asserted, "The chilling effect upon the exercise of First Amendment rights may derive from the fact of the prosecution, unaffected by the prospects of its success or failure." Id. at 487 . It granted relief to avoid "making vindication of freedom of expression await the outcome of protracted litigation." Id.

Although more recent cases, on grounds of federalism, have limited the power of the federal courts to enjoin state proceedings, Fiss, Dombrowski, 86 YALE L.J. 1103, 1117-60 (1977), the substantive analysis of First Amendment burdens in the earlier cases has not been questioned. Furthermore, considerations of federalism are not involved in FEC enforcement because the agency enforces only federal laws.

98. Milky Way Prods., Inc. v. Leary, 305 F. Supp. 288, 297 (S.D.N.Y. 1969) (three-judge court, Frankel, J.), aff'd mem. sub nom. New York Feed Co. v. Leary, 397 U.S. 98 (1970). It refused to require an adversary hearing prior to the arrest of an alleged distributor of pornography, noting, "[T] he inhibitions are not aroided by the new procedure plaintiffs want; they are, if anything, pushed back to an earlier time of open contest when the burden of litigation and a species of readier 'defeat' are likely to work their deterrent effects." Id. at 297. Accord, Golden Eagle v. Johnson, 493 F.2d 1179, 1184 (9th Cir. 1974), cert. denied, 419 U.S. 1105 (1975) (arrest of individual claiming religious justification for possession and use of peyote requires no special probable cause determination); Krahm v. Graham, 461 F.2d 703, 709 (9th $\mathrm{Cir}$. 1972) (vacating injunction requiring adversary hearings before future arrests for sale of obscene materials).

99. 380 U.S. 51 (1965).

100. Id. at 58. The Court based this assertion on its view of the institutional differences between courts and agencies. Id. at 57-58 ("Because the censor's business is to censor, there inheres the danger that he may well be less responsive than a court-part of an independent branch of government-to the constitutionally protected interests in free expression."); see Monaghan, supra note 6, at 520-24. 
expensive for many respondents. Political campaigns often are short on time and money and would suffer from the adverse publicity of FEC allegations. An open judicial hearing might impose considerably greater burdens on political expression than a prompt and fair administrative proceeding, even in situations in which the case was ultimately dismissed, and a judicial finding of violation might be more costly and more disruptive than a conciliation agreement. ${ }^{101}$ Therefore, in many FEC cases, judicial determination would be a burden rather than a benefit. To resolve the tension between the two principles, procedures must be sensitive to the circumstances of expression. ${ }^{102}$

\section{B. The FEC's Failure to Meet the Constitutional Tests}

The FEC's procedures violate both First Amendment due process principles: they unnecessarily increase the likelihood of imposing sanctions on protected speech and they generate excessive defense costs.

\section{Danger of Erroneous Determination}

The respondent can best avoid damaging admissions and restrictions on political activity by winning a dismissal of his case at the threshold of conciliation. The obstacles to an effective defense in the FEC's preconciliation proceedings, however, create a significant danger that protected speech will be penalized. The FEC's refusal to reveal the evidentiary basis for its conclusions places a respondent at a considerable disadvantage in any attempt to persuade the Commission to reject the staff's unfavorable recommendations. Even under the less stringent standards of conventional due process, access to evidentiary files may be constitutionally required. ${ }^{103}$ Certainly, under the stricter procedural requirements of the First Amendment, the FEG policy of refusing to

101. See note 36 supra.

During the pendency of the suit, the respondent may feel compelled to desist from the questioned activity in order to avoid augmenting the penalties in the event of an adverse decision. See, e.g., Findings of Fact at 83, FEC v. CLITRIM, No. 78C-1658 (E.D.N.Y. Aug. 22, 1979); Conciliation agreement in MUR 283/350, signed by New Jersey Education Ass'n; Statement of Points and Authorities in Support of Counterclaimants' Motions at $1-2,5,15$, filed by Public Service Research Council and Public Service PAC, in FEC v. National Right to Work Comm., No. 77-2175 (D.D.C., filed Dec. 21, 1977).

102. As the Court wrote in Speiser $v$. Randall, "[T]he operation and effect of the method by which speech is sought to be restrained must be subjected to close analysis and critical judgment in the light of the particular circumstances to which it is applied." 357 U.S. 513,520 (1958).

103. See Mathews v. Eldridge, 424 U.S. 319, 338, $345-46$ (1976) (procedures upheld because agency provided access to relevant evidence, thus reducing danger of error); Morrissey v. Brewer, 408 U.S. 471, 489 (1972) (before final revocation decision, parolee must receive written notice of claimed violations and disclosure of evidence against him). 
give the respondent access to evidentiary material provides inadequate safeguards for accuracy.

Similarly, the respondent's lack of an adequate right of reply in FEC proceedings is constitutionally unacceptable. By denying the respondent a right to oral argument before the Commission, ${ }^{104}$ the FEC creates a substantial risk of erroneous decision. Although conventional due process may not require oral arguments in agency decisionmaking, ${ }^{105}$ the First Amendment cases suggest that the opportunity for oral argument by the respondent is necessary before the Commission decides whether to dismiss or to enter into conciliation. ${ }^{106}$ This protection would help innocent respondents prevail against adverse recommendations by the FEC's legal staff.

The practice of making decisions at all enforcement stages without a statement of reasons inhibits the development of fully articulated and mutually agreed interpretations of facts and law, and thus enhances the danger of erroneous determination. First Amendment due process requires a procedure that "focus[es] searchingly on" whether the expression is protected or unprotected.107 A clearer articulation of the Commission's premises for decisions would promote more careful deliberation on the merits ${ }^{108}$ and reduce the ambiguity and inconsistency of the campaign finance laws. ${ }^{109}$

104. Most critics of the FEC's procedures do not call for full-scale evidentiary hearings. Rather, they advocate oral argument before the Commission-an opportunity for the respondent to discuss the facts and law and to answer the commissioners' questions. See interviews cited notes 61 \& 65 supra.

105. See 2 K. Davis, supra note 54, at $\$ 10.9$; cf. FCC v. WJR, 337 U.S. 265, 274-77 (1949) (competing radio station has no right to oral argument on challenge to new permit; no general due process rule requiring oral argument before agency).

106. The Court has held that the First Amendment requires an adversary judicial proceeding before the imposition of restraints on speech. See Carroll v. President \& Comm'rs of Princess Anne, 393 U.S. 175, 183 (1968); Freedman v. Maryland, 380 U.S. 51, 58 (1965). In Carroll, condemning a state court's ex parte temporary injunction against political rallies, the Court noted that First Amendment adjudication involved imprecise legal standards and turned upon "subtle and controversial considerations and upon a delicate assessment of the particular situation." 'Thus, the Court asserted, "In the absence of evidence and argument offered by both sides and of their participation in the formulation of value judgments, there is insufficient assurance of the balanced analysis and careful conclusions which are essential in the area of First Amendment adjudication." 393 U.S. at 183 .

Applying this reasoning to the FEC's de facto adjudicative proceeding, which deals with inescapably imprecise standards and delicate case-by-case assessments, participation by respondents in Commission deliberations is required.

107. Quantity of Books v. Kansas, 378 U.S. 205, 210 (1964) (quoting Marcus v. Search Warrant, 367 U.S. 71'7, 732 (1961)); cf. Carroll v. President \& Comm'rs of Princess Anne, 393 U.S. 175, 183 (1968) (need for delicate assessment and balanced analysis).

108. See note 75 supra. Statements of reasons by the FEC also would facilitate judicial review, available to the complainant when the FEC dismisses an enforcement case. 2 U.S.C.A. $\$ 437 \mathrm{~g}(\mathrm{a})(8)$ (West Supp. 1980).

109. The advisory opinion process provides insufficient interpretive guidance to politi- 
The Commission's present conciliation policy also creates an undue likelihood that sanctions will be imposed on protected expression. Although acceptance of a conciliation agreement is legally voluntary, the concept of knowing and deliberate waiver of procedural rights ${ }^{110}$ does not apply in the First Amendment area when a party "cooperates" with the government only to avoid threatened compulsion. ${ }^{111}$ In FEC enforcement, innocent respondents under strong political and financial pressures may capitulate to the FEC's demands for admissions of violation, penalties, and unduly broad prohibitions of future activity. ${ }^{112}$

\section{Excessive Defense Costs}

Whether they result in conciliation agreements or litigation, enforcement proceedings often impose unnecessary defense costs on respondents and thereby violate the second principle of First Amendment due process. The preconciliation procedural defects impose greater factfinding costs on respondents ${ }^{113}$ and reduce the likelihood that cases against innocent parties will be dismissed.114 In the conciliation phase, the FEC's initial insistence on an admission of violation and its failure

cal participants. See notes 13 \& 77 supra; cf. United States Civil Serv. Comm'n v. National Ass'n of Letter Carriers, 413 U.S. 548, 572, 575 (1973) (unconstitutional vagueness avoided in Hatch Act enforcement because Commission had evolved rules and definitions of violative conduct on a case-by-case basis).

110. See Frank Irey, Jr., Inc. v. Occupational Safety \& Health Review Comm'n, 519 F.2d 1200, 1206 (3d Cir. 1975) (employer's failure to file timely contest after notification of violation constitutes knowing and intelligent waiver of right to hearing; imposition of penalty does not violate due process).

111. In Bantam Books, Inc. v. Sullivan, 372 U.S. 58 (1963), the "Rhode Island Commission to Encourage Morality in Youth," $i d$. at 59, like the FEC, had no formal power to impose final sanctions; it could only declare that certain literature was unfit for circulation to minors and recommend prosecution by the district attorney. Like the FEC, the commission nevertheless sought to achieve compliance. It successfully used the threat of court proceedings to convince distributors to withdraw objectionable materials from circulation. Although the dissent observed that an "affected" party wishing to "stand his ground" could obtain a court determination, id. at 78 (Harlan, J., dissenting), the majority insisted that the practical effectiveness of the restraint procedure made it unconstitutional. The FEC's procedures create analogous pressures on respondents to enter into conciliation agreements rather than to go to court. Under these circumstances, the waiver principle should not be used to defeat the constitutional requirement of pro. cedural safeguards for freedom of expression. Cf. Freedman v. Maryland, 380 U.S. 51, 58, 59 (1965) (constitutional requirement of judicial determination not satisfied when judicial appeal of censorship decision deterred by expense and delay; censor's decision, in practice, final).

112. See Carroll v. President \& Comm'rs of Princess Anne, 393 U.S. 175, 183, 184 (1968) (order issued in area of First Amendment rights "must be tailored as precisely as possible to the exact needs of the case"); FTC v. Ruberoid Co., 343 U.S. 470, $492-93$ (1952) (Jackson, J., dissenting) (vague cease and desist order provides no guidance to offender or to courts, creating danger of endless litigation).

113. See pp. 1207-08 supra.

114. See pp. 1207-08, 1210-11 supra. 


\section{Federal Election Commission}

to accept more neutral language without time-consuming negotiations contribute directly to respondents' costs without enhancing the effectiveness of enforcement. ${ }^{115}$ If a respondent cannot negotiate an acceptable conciliation agreement, he may decide that vindication of his rights and his political reputation requires a judicial determination. Litigation imposes additional expense and adverse publicity on the respondent. ${ }^{110}$ The economic, political, and personal resources expended by respondents in defending against unnecessarily expensive

FEC enforcement proceedings may deter citizens from fully exercising their rights to political expression. Some respondents have indicated that the complexity, costs, and psychological burdens of FEC conciliation will deter them from future political activity. ${ }^{117}$

\section{Procedural Reforms: Meeting Constitutional Standards}

Once a burden on protected expression has been shown, a procedure is constitutional only if there are no less restrictive alternatives to achieve the government's legitimate objectives. ${ }^{118}$ Administrative efficiency, convenience, and cost savings alone do not constitute a sufficient governmental interest. ${ }^{119}$ FEC procedures serve the legitimate

115. See pp. 1213-14 supra.

116. Litigation may impose a financial burden that respondents can ill afford. See 125 CoNG. REc. S11,212-15 (daily ed. Aug. 1, 1979) (remarks of Sen. Humphrey) (discussing burdens of FEC litigation against financially weak respondents).

117. Responses to conciliation agreement questionnaires, e.g., MUR 321 ("I was totally disillusioned, disappointed, and terribly distressed over the charge and the harassment that followed .... We will soon have no activists and then we're really in trouble."); MUR 597 ("All indicate they will never again get active in politics; serves to take political involvement away from people and vest operations in hands of expensive and costly pros."); MUR Xxx ("This Commission succeeded in keeping me away from politics in the future."); $c f$. Findings of Fact, FEC v. CLITRIM, No. 78C-1658 (E.D.N.Y. Aug. 22, 1979) (FEC investigation and civil suit against local and national committees of lobbying organization has "caused widespread concern among the TRIM leaders and membership, causing some to terminate their native support and making it more difficult to enlist volunteer leadership and help").

118. United States v. O'Brien, 391 U.S. 367, 377 (1968) (interference with free expression justified only if it furthers an "important or substantial governmental interest . . . unrelated to the suppression of free expression; and if the incidental restriction on alleged First Amendment freedoms is no greater than is essential to the furtherance of that interest."); Shelton v. Tucker, 364 U.S. 479, 488 (1960) ("even though the governmental purpose be legitimate and substantial, that purpose cannot be pursued by means that broadly stifle fundamental personal liberties when the end can be more narrowly achieved"). See generally Note, Less Drastic Means and the First Amendment, 78 Yale L.J. 464 (1969).

119. See Speiser v. Randall, 357 U.S. 513,529 (1958) (burden of ascertaining individual facts is no justification for "short-cut procedure which must inevitably result in suppressing protected speech"); cf. Cleveland Bd. of Educ. v. Lafleur, 414 U.S. 632, 647 (1974) (administrative convenience does not justify conclusive presumption of unfitness of woman to teach after fixed period of pregnancy). 
purpose of protecting the electoral process from abuse by requiring public disclosure of campaign finance information ${ }^{120}$ and by limiting the sources and amounts of campaign contributions. ${ }^{121}$ Nevertheless, these goals could be achieved with less danger of erroneous determination and less cost to respondents. ${ }^{122}$ Procedures could be implemented that would satisfy the least-drastic-means test and yet retain the flexibility necessary for effective FEC enforcement.

First, the Commission should provide the respondent with sufficient information to defend himself effectively. If the staff recommends conciliation rather than dismissal, the respondent should receive not only a brief fully setting forth the staff's position but also access to supporting evidentiary material. ${ }^{123}$ If the brief and evidentiary material create a need for additional discovery, the respondent should be granted reasonable extensions of time in which to secure the needed information. While adding only marginally to the cost of FEC enforcement, these reforms would markedly increase its fairness. In addition, the formal requirement may encourage the staff to provide more information voluntarily to respondents prior to the final report.

Second, the FEC should permit respondents to make oral arguments to the Commission before it decides whether to enter into conciliation. Oral argument would enhance the fairness and hence the legitimacy of the procedure. Because of its expense to respondents, oral argument would create only limited additional demands on the Commission's time. ${ }^{124}$

Third, the Commission should provide a formal statement of reasons for each of its enforcement decisions, whether it dismisses a case or proceeds into investigation, conciliation, or litigation. Adoption of the staff report's arguments would be sufficient in most cases. Further-

120. Buckley v. Valeo, 424 U.S. I, $60-84$ (1976).

121. Id. at 23-38.

122. Safeguards would increase the likelihood of dismissing appropriate cases, even if they lengthen the enforcement process in earlier stages. If a violation has occurred, a lengthier enforcement process would not be less effective, because FEC enforcement does not currently depend on promptly publicizing violations before an election campaign is over. Cases are rarely resolved against respondents until after the election. Author's analysis of enforcement files. Investigations must be kept confidential while in progress, 2 U.S.C.A. $\$ 437 \mathrm{~g}(\mathrm{a})(12)$ (West Supp. 1980).

123. Disclosure of the staff's conclusions and evidentiary supporting materials at the preconciliation stage balances the interests of the respondent in preparing an effective defense with the need of the staff for confidentiality during the course of its investigation. See pp. 1208-09 supra. A similar balance is sought in the rules governing pretrial discovery. Hickman v. Taylor, 329 U.S. 495, 501, 510-12 (1947) (discussing purposes of discovery in Federal Rules of Civil Procedure). Although the FEC proceeding is not a formal adjudication, it has sufficient adversarial elements for the litigation analogy to be instructive.

124. See p. 1211 supra. 
more, when the Commission takes enforcement action, it should act in a manner consistent with prior decisions or with a previously announced change in policy.

Finally, the Commission should employ a more flexible conciliation policy, acknowledging its de facto adjudicative as well as its prosecutorial role. Instead of demanding admissions of violation as a matter of policy in conciliation proceedings, the FEC should more readily accept neutral language when the issues of fact or law are unclear. ${ }^{125}$ This approach would reduce the likelihood that respondents who have not violated the law will be forced to admit a violation and pay a penalty. It also would save respondents and the government considerable expense by allowing conciliation agreements to be concluded more quickly and by reducing the pressure to litigate for vindication. ${ }^{126}$

These proposed changes in FEC enforcement policies would create a hybrid, intermediate procedure ${ }^{127}$ that would recognize the reality of the FEC's role in enforcing federal campaign laws and that would conform to the constitutional standards of First Amendment due process. The changes would preserve the advantages of internal agency resolution of routine cases ${ }^{128}$ and de novo court review for large and com-

125. In its decisions during conciliation in disputed cases, the FEC should recognize the First Amendment chilling effect of admitting a violation or defending a lawsuit. This recommendation does not require the FEC to decide that portions of its statute are unconstitutional, a power committed to courts rather than to agencies. See $3 \mathrm{~K}$. DAvis, supra note 38, $\$ 20.04$, at 74 (1st ed. 1958). It calls for greater First Amendment sensitivity in statutory interpretation, not for disregard of the statute.

In addition, conciliation agreements should include narrow, specific promises not to engage in future violations rather than the broad, vague language frequently used in past agreements. See notes $82 \& 112$ supra (FEC practice of requiring broadly worded promises in conciliation agreements).

126. A modified FEC conciliation policy would not substantially reduce the opportunities for clarification of the statute, even if it reduced the number of enforcement suits. In recent cases, district courts have dismissed FEC suits on the ground that the FEC has not sufficiently defined the statute's requirements, but the courts have not undertaken such interpretation themselves. See, e.g., FEC v. Committee for a Constitutional PresidencyMcCarthy "76, Fed. Ei.ection CAMpaign Financing Guide (CCH) If 9074 (D.D.C. March 7, 1979); FEC $\checkmark$. Citizens for the Republic, No. 78-1160 (D.D.C., defendant's motion for summary judgment granted, March 1, 1979); OPEN Politics ReporT, March 1979, at 2-3 (published by Committee for a Constitutional Presidency, Washington, D.C.).

127. The procedure set forth in this Note fits neither of the traditional administrative law categories: on the one hand, investigative and prosecutorial procedures that require no safeguards because later court review is provided and, on the other hand, formal adjudicative proceedings requiring a full trial-type hearing. K. Davis, Administrative Law Texr $\$ 4.07$ ( $3 \mathrm{~d}$ ed. 1972) (though courts tend to refuse middle position between requiring and not requiring trial-type hearing, less cumbersome procedural protection is desirable); see p. 1206 supra.

128. The hybrid procedure does allow for the imposition of some penalties without judicial determination or evidentiary hearing; this is constitutionally acceptable. The major substantive provisions of the Federal Election Campaign Act, as it now stands, have been upheld by the Supreme Court. Buckley v. Valeo, 424 U.S. 1 (1976). In a significant 
plex cases, ${ }^{129}$ while providing additional safeguards for respondents facing the FEC's de facto adjudication. ${ }^{130}$ They would greatly reduce the danger that administrative sanctions and restraints might penalize or chill constitutionally protected political activity. They also would reduce the procedural costs to all parties. Thus, they offer a workable balance between the competing First Amendment requirements of assuring accuracy and avoiding unnecessary burdens on respondents.

number of clear-cut cases, see note 41 stura, there will be no dispute about the Commission's finding of a violation. In these cases, administrative sanctions do not create an undue danger of erroneous determinaton, and they do avoid unnecessary costs for respondents. In disputed small cases, internal agency resolution, with the safeguards suggested in this Note, see pp. 1222-23 supra, is the "least drastic means" for enforcement of the law against violators.

129. The procedure is not sufficiently elaborate to supersede de novo review in court and thus to permit the less rigorous standard of "substantial evidence" review. See, e.g., 5 U.S.C. $\$ 706(2)$ (E) (1976). See generally K. Davis, Administrative LAw 75-78 (6th ed. 1977) (discussing "substantial evidence" standard). Thus, for those respondents with the incentive and resources to defend themselves in litigation, the fact-finding will be made by the court. See p. 1207 supra (court's fact-finding capacity superior to FEC's).

130. Cf. K. Davis, Administrative Law of the Scventies $\$ 7.00-13$ (Supp. 1978) (importance of developing new concept of "fair informal procedure" to be applied whenerer person's protected interest is threatened by agency decisionmaking; concept should be more flexible than old concept of "fair trial"). 